\title{
Mangrove forests associated with salt flats: a case study from southeast Brazil
}

\author{
Mario Luiz Gomes Soares ${ }^{1 *}$, Filipe de Oliveira Chaves ${ }^{I}$, Gustavo Calderucio Duque Estrada ${ }^{1}$, \\ Viviane Fernandez ${ }^{2}$
}

\author{
${ }^{1}$ Núcleo de Estudos em Manguezais, Faculdade de Oceanografia da UERJ \\ (R. São Francisco Xavier, 524, Maracanã, Rio de Janeiro - RJ, 20550-900) \\ ${ }^{2}$ Departamento de Análise Geoambiental da UFF \\ (Avenida Litorânea, s/n - Boa Viagem - Niterói RJ - 4º andar - CEP 24.030-346) \\ *Corresponding author: mariolgs@uerj.br
}

\begin{abstract}
In this study, forest structure variability of a mangrove associated to a salt flat in Sepetiba Bay (SE-Brazil) was assessed. Forest structure and interstitial water salinity were measured in 32 plots established along three transects ranging from the margin of the estuary to the transition with the salt flat. Structural development was shown to be highly variable, with mean height ranging from $0.54 \mathrm{~m}$ to $7.96 \mathrm{~m}$, mean diameter ranging from $1.58 \mathrm{~cm}$ to $9.46 \mathrm{~cm}$ and trunk density ranging from 2,733 live trunks.ha ${ }^{-1}$ to 106,667 live trunks.ha ${ }^{-1}$. Forest structure variability responded to the gradient of increasing interstitial water salinity towards the salt flat, with mean height and diameter decreasing and trunks density increasing progressively in the same direction. The following pattern of species dominance was observed: Rhizophora mangle near the estuary margin; Laguncularia racemosa at the transition with the salt flat; and Avicennia schaueriana on intermediate zones. The assessment of structural characteristics of mangrove forests and their relationships with natural stressors (e.g., salinity) contribute to better understand the dynamics of the species along coastal plains associated with preserved salt flats, such as the one found in Guaratiba.
\end{abstract}

Descriptors: Mangrove, Phytosociology, Salt Flats, Ecological Gradients

\section{RESUmo}

No presente estudo, a variabilidade estrutural de uma floresta de mangue associada a uma planície hipersalina na Baía de Sepetiba (SE-Brasil) é analisada. A estrutura vegetal e a salinidade da água intersticial foram medidas em 32 parcelas estabelecidas ao longo de 3 transectos localizados desde a margem do estuário até a transição com a planície hipersalina. O desenvolvimento estrutural foi altamente variável, com altura média variando entre $0,54 \mathrm{~m}$ e 7,96 m, diâmetro médio entre $1,58 \mathrm{~cm}$ e 9,46 $\mathrm{cm}$ e densidade de troncos entre 2.733 troncos vivos.ha ${ }^{-1}$ e 106.667 troncos vivos.ha ${ }^{-1}$. A variabilidade da estrutura vegetal respondeu ao gradiente de aumento da salinidade da água intersticial à planície hipersalina, com a altura e o diâmetro médios diminuindo e a densidade de troncos aumentando no mesmo sentido. O seguinte padrão de dominância de espécies foi observado: Rhizophora mangle nas proximidades da margem do estuário; Laguncularia racemosa na transição com a planície hipersalina; e Avicennia schauerianna nas zonas intermediárias. $\mathrm{O}$ entendimento das características estruturais das florestas de mangue e suas relações com estressores naturais (ex. salinidade) contribuirá para a melhor compreensão da dinâmica das espécies ao longo de planícies costeiras associadas à planícies hipersalinas bem preservadas como em Guaratiba.

Descritores: Manguezal, Fitossociologia, Planícies hipersalinas, Gradientes ecológicos. 


\section{INTRODUCTION}

Mangroves are coastal ecosystems located in intertidal zones of tropical and subtropical regions around the world. According to WALSH (1974), mangroves occur and are more developed in sites where the average minimum temperature of the coldest month of the year is higher than $20^{\circ} \mathrm{C}$ and the annual temperature range is lower than $5^{\circ} \mathrm{C}$. They typically occur on muddy substrates protected from wave action and subjected to large tidal amplitudes.

Although these factors generally control the occurrence of mangroves worldwide, the structural and functional characteristics of each mangrove forest are regulated by an interaction of factors that act at the regional scale ("the energy signature"), as described by SCHAEFFER-NOVELLI et al. (1990) and TWILLEY (1995), and the local scale (e.g., factors associated with the frequency of tidal flooding) (SOARES et al., 2003). SOARES et al. (2003) further observed that the structure of mangroves reflects an overlay of characteristics associated with disturbances, namely: (1) type (chronic or acute); (2) spatial variability; (3) variable action over time; (4) variable frequency (recurrence); and (5) the system's capacity to recover after disturbances. OLIVER; LARSON (1990), HUSTON (1996), and FRELICH (2002) have described the mosaic pattern of several plant communities. SMITH (1992), SOARES (1999), SOARES et al. (2003), and BERGER et al. (2008) addressed this mosaic structure more specifically for mangrove forests.

Because mangroves occur in intertidal zones, soil salinity is a key environmental factor controlling the structure, function and distribution of this ecosystem. Mangrove species are generally adapted to survive under high salinity conditions (WALSH, 1974; LUGO; SNEDAKER, 1974; CHAPMAN, 1976). CINTRON et al. (1978) have proposed the upper limit of tolerance for mangrove species as being 2.5 times higher than the average salinity of sea water (35), a level that would allow plants to extract fresh water from saline water.

Although mangrove species have morphological and physiological adaptations for occurring in saline soils, growth and survivorship decline with increasing salinity. BALL (1980) have shown that salinity acts on the inter- and intraspecific competitive abilities of mangrove species and that salt stress limits growth and reproduction of plants. Extremely high salt concentrations in tropical salt flats are responsible for the absence of macrophytes (RIDD; SAM, 1996).
Some studies have characterized the structure of mangrove forests in the state of Rio de Janeiro (Southeast Brazil), such as Paraíba do Sul River (BERNINI; REZENDE, 2004), Guanabara Bay (SOARES et al., 2003; CAVALCANTI et al., 2009), Tijuca Lagoon (SOARES, 1999) and Sepetiba Bay (SILVA et al., 1991; ESTRADA et al., 2013), but adequate characterization of mangroves in some key regions is still lacking. This is the case of Guaratiba (located in Sepetiba Bay), one of the most important remnants of this ecosystem in the state of Rio de Janeiro. The same is true for mangrove forests associated with salt flats throughout the Brazilian coast.

To fill this gap, a case study from a well-preserved mangrove located in Sepetiba Bay is presented, describing the structural variability and its relationship with environmental gradients and, more specifically, the relationship between low structural development with environmental severity at the transition zone between the mangrove forest and the salt flat. Three hypotheses were defined in order to meet this objective: 1) Structural development of the mangrove forest decreases as the environmental severity towards the salt flat increases; 2) Relative dominance of species change in response to the increase in environmental severity; 3) Space is not optimally occupied in sites with extreme environmental severity for mangrove species.

\section{MATERIAL AND METHODS}

\section{STUDY AREA}

The study area is located at the Sepetiba/Guaratiba coastal plain, on the west side of the city of Rio de Janeiro, SE-Brazil. According to Köppen's classification, the climate in this region's coastal plain is Aw - tropical, hot and humid, with dry winters - and in its adjacent mountain slopes is Af, tropical, hot and humid, without dry seasons. The annual mean temperature is $23.5^{\circ} \mathrm{C}$ and the annual mean rainfall reaches $1,067 \mathrm{~mm}$ (ESTRADA et al., 2008). January and March are the wettest months and June and August the driest. The potential evapotranspiration in the region is higher from February to April and lower from June to September. The region is characterized by a microtidal regime. Groundwater from the Guaratiba Aquifer flows at shallow depths $(1.5 \mathrm{~m})$ from the adjacent higher lands to the coastal plain, reaching the estuarine system (VICENTE et al., 2010).

The mangroves of Guaratiba are located on the east side of Sepetiba Bay, between the Piraquê River and the 
Guaratiba Mountain. They integrate a system of islands, rivers and channels that constitute the Guaratiba Biological Reserve (Figure 1A, B). Three typical mangrove species occur on the site: Avicennia schaueriana Stapf \& Leechm. ex Moldenke, Laguncularia racemosa (L.) C.F. Gaertn., and Rhizophora mangle L. The most inner parts of the intertidal zone are only reached by spring tides, leading to the formation of salt flats: high-intertidal sites occurring in arid or seasonally dry regions (evapotranspiration higher than precipitation) and subjected to low tidal flooding, driving hypersaline conditions in the soil (HUTCHINGS; SAENGER, 1987). There is a continuum of features in Guaratiba that belong to the mangrove ecosystem, as described by HUTCHINGS; SAENGER (1987): (a) mud flats in the zones below mean sea level; (b) mangrove forests in the zones above mean sea level and below the highest neap tides level; and (c) salt flats, located in areas above the zone reached by the highest neap tides and up to the average high spring tides level. The mangrove forests of Guaratiba occupy an area of $20.9 \mathrm{~km}^{2}$ and the salt flats $7.4 \mathrm{~km}^{2}$. Previous studies describing the forest structure of the Guaratiba mangroves were undertaken by DANSEREAU (1947) and ESTRADA et al. (2013). The former was strictly descriptive and only provided general distribution diagrams of mangrove species, while the later analyzed the structural properties in order to test suitability of the concept of physiographic types.

\section{SAMPLING DESIGN}

The present study was developed in the mangroves occurring in the Piracão River, one of the three rivers that flow onto the Guaratiba coastal plain (Figure 1A, B). In the middle stretch of this river, 32 plots were established. They were positioned along three transects (A, B, and C), from the margin of the river to the interface between the mangrove forest and the salt flat. Plots inside the transects were distributed as follows: 8 at transect A, 10 at B e 14 at $\mathrm{C}$.

CINTRON; SCHAEFFER-NOVELLI (1984) provided a general overview of the method used to characterize the structure of mangrove forests. To sample a representative number of individuals (trees), plots ranging from 15 to $150 \mathrm{~m}^{2}$, depending on the forest density, were delimited at each sampling site. In addition, homogeneity of structural characteristics (species composition and structural development of individuals) was also taken into consideration. At each plot, all individuals were identified to the species level, had their height and trunk diameter measured, and were classified according to the condition of their trunks (live or dead). Trunk diameter was measured at $1.30 \mathrm{~m}$ from the ground and denoted by $\mathrm{D}_{130}$ (BROKAW; THOMPSON, 2000). However, in plot A7, located at the transition zone between the forest and the salt flat, the trees were shorter and shrubby, and hence the diameter was measured at the trunk base.

Once field data had been collected, mean height, mean $\mathrm{D}_{130}$, basal area, relative basal area dominance and density of trunks were calculated. Basal area $\left(\mathrm{g}\right.$, in $\left.\mathrm{m}^{2} \cdot \mathrm{ha}^{-1}\right)$ was calculated by the formula $g=0.00007854 *\left(D_{130}\right)^{2}$. Mean $\mathrm{D}_{130}$ represents the diameter (in $\mathrm{cm}$ ) of the tree with the mean basal area. Note that this parameter differs from the arithmetic mean of $\mathrm{D}_{130}$ 's. Mean $\mathrm{D}_{130}$ was calculated by applying live basal area data to the formula:

$=\left[(\mathrm{g})^{*} 12732.39 / \mathrm{n}\right]^{1 / 2}$, where $\mathrm{n}=$ the number of trunks per hectare and $\mathrm{g}=$ basal area.

Using the Statistica $6.0 \AA$ package, a cluster analysis (UPGMA) was applied to the data to analyze the relationships between the structural parameters of forests and the position along the tidal gradient. The parameters adopted for these analyses were mean $\mathrm{D}_{130}$ and the mean height. A second cluster was run using the relative contribution (\%) of each species' live basal area. A regression analysis was run to assess the relationship between trunk density and mean height.

Based on the position of each plot along the transects and on a micro-topographic assessment previously presented by ESTRADA et al. (2013) for the mangroves of Guaratiba, the sampling plots were classified in terms of physiographic types, using the approach proposed by the same authors: fringe forests (sites at the low intertidal zone, with high tidal flooding frequency); basin forests (sites at the intermediate intertidal zone, with intermediate tidal flooding frequency); and transition forests (sites at the transition of the forest and the salt flat, at the high intertidal zone and presenting very low tidal flooding frequency). Plots grouped as physiographic types were compared for trunk density, mean height and mean $\mathrm{D}_{130}$ using ANOVA and Tukey post-hoc test $(\mathrm{p}<0.05)$.

Assessment of interstitial water salinity was conducted at eight different sites along the tidal flooding gradient inside the mangrove forest (transect A), the first site located near the river margin and the last one at the interface between the mangrove forest and the salt flat. In each of the sampling points, holes were dug in the sediment to the depth where water seeped in. Salinity was assessed in triplicate (three different holes) using an optical 
A)

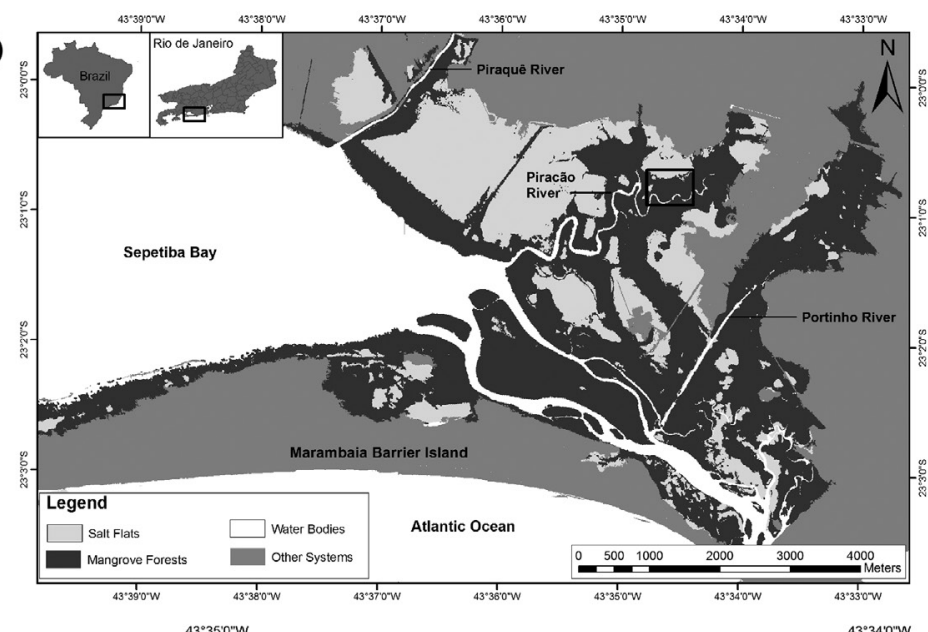

B)

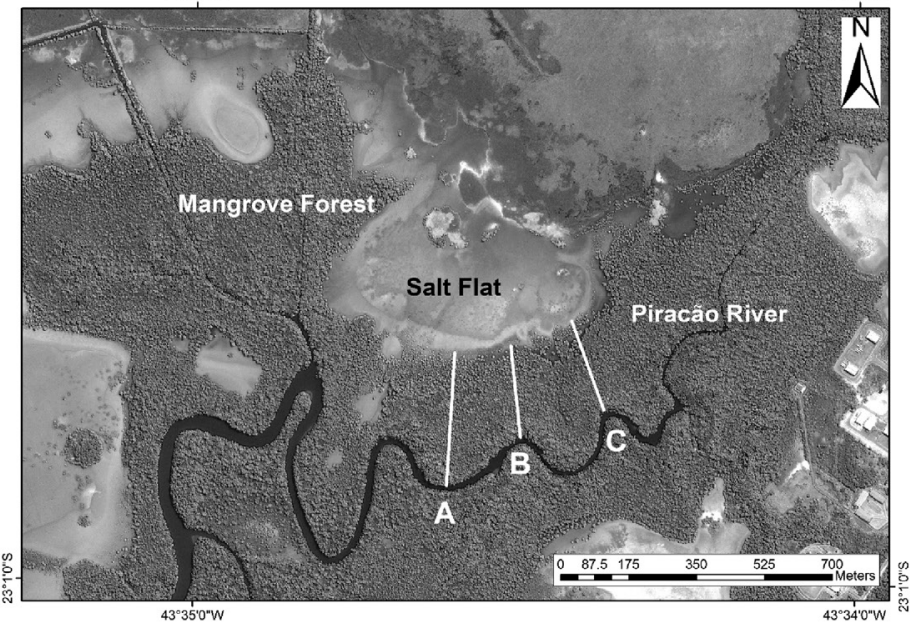

Figure 1. (A) Map showing the study area, with sampling location indicated (black square). Mangrove forests are presented in dark gray and areas in light gray represent salt-flats. (B) Aerial photograph $(1: 6,000)$ of the sampling site (black square in figure $1 \mathrm{~A})$ indicating the position of transects $\mathrm{A}, \mathrm{B}$ and $\mathrm{C}$.

refractometer model A366ATC (American Optical), with maximum range of 160 and accuracy of 1 unit.

Differences in the salinity of interstitial water between the eight sites were assessed by the Kruskal-Wallis test.

\section{RESULTS}

Mean salinity ranged from 28 at point two to 44 at point eight. There were significant differences in interstitial salinity among sites $(\mathrm{KW}=280.35 ; \mathrm{p}<0.01)$. Salinity of the interstitial water increased landward and was correlated with the distance from the river $\left(\mathrm{p}<0.05 ; \mathrm{R}^{2}\right.$ $=0.768$; Figure 2). In the present study, points one to six were regularly flooded by neap tides and points seven and eight were flooded only during spring tides. The duration of flooding was greater at sites closer to the river. Higher salinity at point eight is probably due to the combined effect of lower frequency of tidal flooding and evaporation of standing water. On the other hand, lower salinity at point two is explained by higher frequency of tidal flooding.

The distribution of mangrove species along the transects reveals a pattern of zonation, inferred from the relative contribution of each species to the basal area (Tables 1, 2, and 3). This pattern is characterized by a general tendency toward dominance of $R$. mangle near the margin of the Piracão River, A. schaueriana between the margin and the salt flat, and L. racemosa closer to the salt flat. However, some exceptions to this pattern occurred in transect $\mathrm{A}$, such as the co-dominance of $A$. schaueriana and $R$. mangle at plot one, and the dominance of $A$. schaueriana at plot eight. 


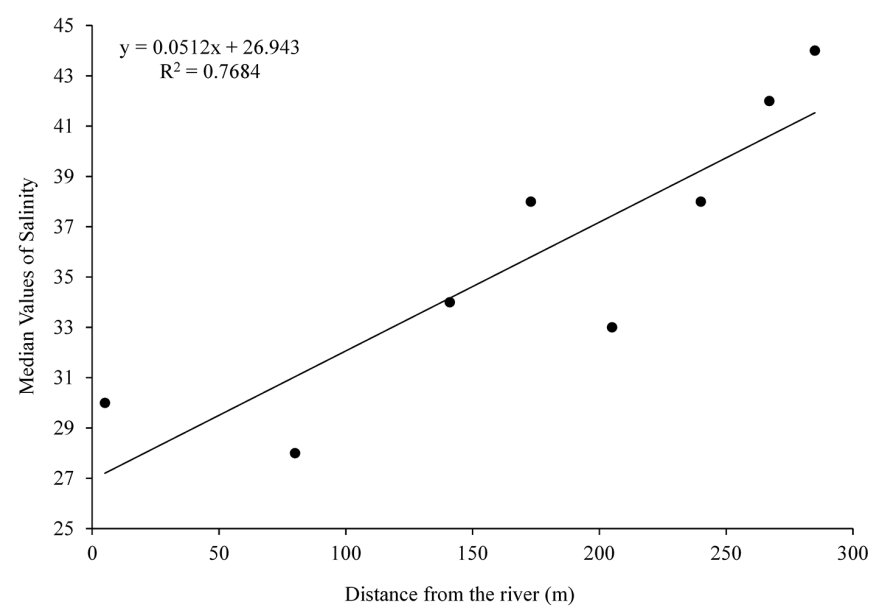

Figure 2. Regression analysis relating interstitial water salinity and distance from Piracão River.

The structural development of the three transects showed high variability. Mean height ranged from $0.54 \pm$ 0.46 to $7.96 \pm 1.73 \mathrm{~m}$ and mean $\mathrm{D}_{130}$ from 1.58 to $9.46 \mathrm{~cm}$ (Tables 1, 2, and 3). Trunk density also reflected this high variability, ranging from 2,733 to 106,667 live trunks.ha-1 ${ }^{-1}$. When each transect is analyzed individually, a tendency of decreasing structural development is evident from the margin of the Piracão River to the transition zone, at the interface between the mangrove forest and the salt flat. Hence, as mean height and $\mathrm{D}_{130}$ decrease, trunk density increases progressively (Tables 1, 2, and 3).

The tendency of structural development decrease towards the transition zone was also confirmed by changes in basal area. The distribution of basal area by $\mathrm{D}_{130}$ classes (Tables 4, 5, and 6) revealed that trunks above $10 \mathrm{~cm}$ are concentrated at sites closer to the river and are replaced by intermediate and smaller classes toward the transition zone.

The regression between trunk density and mean height for these forests showed an inverse relationship (Figure $3 \mathrm{~A} ; \mathrm{R}^{2}=0.69 ; p<0.05$ ). It means that density decreases and size increases as forest development takes place. However, there was also a group of plots with low mean height $(0.54 \pm 0.46$ to $1.58 \pm 0.98 \mathrm{~m})$ and low trunk density $\left(12,667\right.$ to 45,714 live trunks.ha' $\left.{ }^{-1}\right)$ : A5, A6, A7, $\mathrm{A} 8, \mathrm{~B} 10, \mathrm{C} 12, \mathrm{C} 13$, and $\mathrm{C} 14$. These plots are located at the transition with the salt flat. When these plots were excluded from the analysis, this relationship became even stronger (Figure 3B; $\mathrm{R}^{2}=0.81 ; p<0.05$ ).

A cluster analysis considering mean $\mathrm{D}_{130}$ and height revealed four groups (Figure 4A). Group (A) represents sampling sites located close to the margin of the Piracão River, where tidal flooding frequency is higher. These sites showed higher structural development, mean $\mathrm{D}_{130}$ above $7.0 \mathrm{~cm}$, and mean height above $7.0 \mathrm{~m}$. These sites are dominated by $R$. mangle, with a considerable contribution of $A$. schaueriana and the presence of few L. racemosa individuals (Tables 1, 2, and 3). Group (B) represents sampling sites near the Piracão River, with $\mathrm{D}_{130}$ between 4.5 and $7.0 \mathrm{~cm}$ and a mean height lower than $7.0 \mathrm{~m}$. Hence, plots in Group (B) show intermediate structural development. These forests are dominated by A. schaueriana but have considerable contribution of $R$. mangle (Tables 1, 2, and 3). Groups (C) and (D) represent forests with lower structural development, with mean $\mathrm{D}_{130}$ lower than $4.5 \mathrm{~cm}$ (Tables 1, 2, and 3). Plots in Group (C) are located at intermediate distance between the Piracão River and the salt flat. Although they present low mean $\mathrm{D}_{130}$, mean height is above $2.0 \mathrm{~m}$, as opposed to plots in Group (D), located closer to the salt flat, where mean height is below $2.0 \mathrm{~m}$ (Tables 1, 2, and 3). Both groups are dominated by $L$. racemosa and/or A. schaueriana. However, Group (C) shows the occurrence of few $R$. mangle trees in some plots. As presented earlier by the regression analysis (Figure 3A) plots A5, A6, A7, A8, B10, $\mathrm{C} 12, \mathrm{C} 13$, and $\mathrm{C} 14$ do not follow the general relationship between mean height and trunk density. According to the cluster analysis, these plots fall into Group (D). The only exception is plot A7, which is isolated in Group (B), probably because diameter was measured at the trunk base in this plot, as described in the Methods section, leading to an overestimated average. 
Table 1. Structural parameters of transect A.

\begin{tabular}{|c|c|c|c|c|c|c|c|}
\hline \multirow{2}{*}{ Plot } & \multirow{2}{*}{$\begin{array}{l}\text { Density (live } \\
\text { trunks.ha }{ }^{-1} \text { ) }\end{array}$} & \multirow{2}{*}{$\begin{array}{l}\text { Mean } D_{130} \\
(\mathrm{~cm})\end{array}$} & \multirow{2}{*}{$\begin{array}{l}\text { Mean Height } \\
\text { (m) }\end{array}$} & \multirow{2}{*}{$\begin{array}{l}\text { Basal Area } \\
\left(\mathrm{m}^{2} \cdot \mathrm{ha}^{-1}\right)\end{array}$} & \multicolumn{3}{|c|}{ Basal Area Contribution (\%) } \\
\hline & & & & & Species & Live & Dead \\
\hline \multirow{3}{*}{1} & \multirow{3}{*}{4,100} & \multirow{3}{*}{8.77} & \multirow{3}{*}{$7.63 \pm 1.41$} & \multirow{3}{*}{26.11} & R. mangle & 43 & 2 \\
\hline & & & & & L. racemosa & 6 & 2 \\
\hline & & & & & A. schaueriana & 45 & 1 \\
\hline \multirow{3}{*}{2} & \multirow{3}{*}{2,733} & \multirow{3}{*}{9.46} & \multirow{3}{*}{$7.40 \pm 1.97$} & \multirow{3}{*}{20.15} & R. mangle & 62 & 2 \\
\hline & & & & & L. racemosa & 18 & 2 \\
\hline & & & & & A. schaueriana & 16 & 1 \\
\hline \multirow{3}{*}{3} & \multirow{3}{*}{9,800} & \multirow{3}{*}{5.16} & \multirow{3}{*}{$4.19 \pm 1.77$} & \multirow{3}{*}{25.13} & R. mangle & 28 & 3 \\
\hline & & & & & L. racemosa & 6 & 1 \\
\hline & & & & & A. schaueriana & 48 & 14 \\
\hline \multirow{3}{*}{4} & \multirow{3}{*}{13,400} & \multirow{3}{*}{3.57} & \multirow{3}{*}{$3.28 \pm 1.76$} & \multirow{3}{*}{15.14} & R. mangle & 7 & 0 \\
\hline & & & & & L. racemosa & 18 & 5 \\
\hline & & & & & A. schaueriana & 63 & 6 \\
\hline \multirow{3}{*}{5} & \multirow{3}{*}{34,400} & \multirow{3}{*}{2.3} & \multirow{3}{*}{$1.34 \pm 0.86$} & \multirow{3}{*}{15.03} & R. mangle & 0 & 0 \\
\hline & & & & & L. racemosa & 55 & 4 \\
\hline & & & & & A. schaueriana & 40 & 1 \\
\hline \multirow{3}{*}{6} & & & & & R. mangle & 0 & 0 \\
\hline & 45,714 & 4.15 & $1.07 \pm 0.45$ & 62.14 & L. racemosa & 86 & 0 \\
\hline & & & & & A. schaueriana & 13 & 1 \\
\hline & & & & & R. mangle & 0 & 0 \\
\hline 7 & 12,667 & 7.23 & $1.24 \pm 0.19$ & 51.96 & L. racemosa & 100 & 0 \\
\hline & & & & & A. schaueriana & 0 & 0 \\
\hline & & & & & R. mangle & 0 & 0 \\
\hline 8 & 33,667 & 3.74 & $0.80 \pm 0.29$ & 37.24 & L. racemosa & 0 & 0 \\
\hline & & & & & A. schaueriana & 99 & 1 \\
\hline
\end{tabular}

Cluster analysis considering species contribution to live basal area (Figure 4B) followed the same general pattern obtained in the structural development analysis. Group (I) includes plots with more than $20 \%$ of $R$. mangle. These plots are all included in Groups (A) and (B). Group (II) constitutes forests dominated by $A$. schaueriana and is almost identical to Group (C). Finally, Group (III) is characterized by forests with contribution of L. racemosa higher than 55\%, no $R$. mangle individuals, and is equivalent to Group (D).

Considering the criteria described in the methods section, plots were grouped as physiographic types as follows: Fringe forests $-\mathrm{A} 1, \mathrm{~A} 2, \mathrm{~B} 1, \mathrm{~B} 2, \mathrm{~B} 3, \mathrm{C} 1$ and $\mathrm{C} 2$; Basin Forests - A3, A4, B4, B5, C3, C4, C5, C6, C7, C8, C9 and C10; Transition Forests - A5, A6, A7, A8, B6, B7, $\mathrm{B} 8, \mathrm{~B} 9, \mathrm{~B} 10, \mathrm{C} 11, \mathrm{C} 12, \mathrm{C} 13$ and $\mathrm{C} 14$. The results confirm significant differences for all the parameters: Trunk density $(\mathrm{F}=44.98$; $\mathrm{p}<0.01)$; Mean $\mathrm{D}_{130}(\mathrm{~F}=313.85$; $\mathrm{p}$ $<0.01)$; and Mean height $(\mathrm{F}=499.58$; $\mathrm{p}<0.01)$. Tukey test confirmed significant differences between fringe and transition forests for all parameters. However, this was the only significant difference for trunk density $(p=0.001)$, while for mean $\mathrm{D}_{130}$ only basin versus transition had no difference $(\mathrm{p}<0.721)$. Mean height was significantly different in all cases $(\mathrm{p}<0.01)$.

Table 7 compares the results of the present study to the ones presented previously to other mangroves from the state of Rio de Janeiro, which are located in a narrow latitudinal range, between $21^{\circ} 18^{\prime}$ and $23^{\circ} 23^{\prime} \mathrm{S}$, and in the same coastal segment (Schaeffer-Novelli et al., 2000). In terms of mean $\mathrm{D}_{130}$ and height, mangrove forests in the Piracão River vary from low to intermediate structural development compared to other mangroves in the state. Basal area is within range found for other forests in this regions. The exceptions are sampling plots 6 and 7 of transect $\mathrm{A}$ and plot 8 of transect $\mathrm{C}$, where basal area is much larger.

\section{DISCUSSION}

The pattern of species distribution observed in Guaratiba is typical of mangrove forests located in south and southeast Brazil (SCHAEFFER-NOVELLI et al., 1990), where only $R$. mangle, L. racemosa, and $A$. schaueriana occur. A similar pattern has been described by SHERMAN et al. (2000), LARA; COHEN (2006), and PIOU et al. (2006) for other regions where $R$. mangle, $L$. 
Table 2. Structural parameters of transect B.

\begin{tabular}{|c|c|c|c|c|c|c|c|}
\hline \multirow{2}{*}{ Plot } & \multirow{2}{*}{$\begin{array}{c}\text { Density (live } \\
\text { trunks.ha-1) }\end{array}$} & \multirow{2}{*}{$\begin{array}{l}\text { Mean } D_{130} \\
\quad(\mathrm{~cm})\end{array}$} & \multirow{2}{*}{$\begin{array}{c}\text { Mean } \\
\text { Height (m) }\end{array}$} & \multirow{2}{*}{$\begin{array}{c}\text { Basal Area } \\
\left(\mathrm{m}^{2} \cdot \mathrm{ha}^{-1}\right)\end{array}$} & \multicolumn{3}{|c|}{ Basal Area Contribution (\%) } \\
\hline & & & & & Species & Live & Dead \\
\hline & & & & & R. mangle & 48 & 7 \\
\hline \multirow[t]{3}{*}{1} & 5,100 & 7.37 & $7.71 \pm 1.48$ & 26.62 & L. racemosa & 0 & 3 \\
\hline & & & & & A. schaueriana & 34 & 8 \\
\hline & & & & & R. mangle & 33 & 6 \\
\hline \multirow[t]{3}{*}{2} & 5,700 & 6.31 & $5.61 \pm 2.26$ & 21.11 & L. racemosa & 0 & 3 \\
\hline & & & & & A. schaueriana & 51 & 7 \\
\hline & & & & & R. mangle & 32 & 1 \\
\hline \multirow[t]{3}{*}{3} & 6,400 & 5.86 & $5.04 \pm 1.14$ & 25.83 & L. racemosa & 7 & 1 \\
\hline & & & & & A. schaueriana & 28 & 30 \\
\hline & & & & & R. mangle & 25 & 4 \\
\hline \multirow[t]{3}{*}{4} & 15,143 & 4.56 & $3.05 \pm 1.75$ & 27.35 & L. racemosa & 8 & 2 \\
\hline & & & & & A. schaueriana & 58 & 3 \\
\hline & & & & & R. mangle & 15 & 0 \\
\hline \multirow[t]{3}{*}{5} & 15,143 & 4.56 & $3.05 \pm 1.75$ & 27.35 & L. racemosa & 21 & 9 \\
\hline & & & & & A. schaueriana & 44 & 11 \\
\hline & & & & & R. mangle & 0 & 0 \\
\hline \multirow[t]{3}{*}{6} & 23,250 & 3.62 & $2.88 \pm 1.51$ & 27.08 & L. racemosa & 16 & 5 \\
\hline & & & & & A. schaueriana & 72 & 7 \\
\hline & & & & & R. mangle & 0 & 0 \\
\hline \multirow[t]{3}{*}{7} & 41,250 & 2.5 & $2.46 \pm 1.23$ & 23.12 & L. racemosa & 25 & 6 \\
\hline & & & & & A. schaueriana & 63 & 7 \\
\hline & & & & & R. mangle & 0 & 0 \\
\hline \multirow[t]{3}{*}{8} & 69,714 & 2.25 & $1.55 \pm 0.94$ & 29.43 & L. racemosa & 63 & 4 \\
\hline & & & & & A. schaueriana & 32 & 2 \\
\hline & & & & & R. mangle & 0 & 0 \\
\hline \multirow[t]{3}{*}{9} & 85,333 & 1.61 & $1.57 \pm 0.46$ & 21.17 & L. racemosa & 71 & 18 \\
\hline & & & & & A. schaueriana & 11 & 0 \\
\hline & & & & & R. mangle & 0 & 0 \\
\hline \multirow[t]{2}{*}{10} & 36,000 & 3.15 & $0.60 \pm 0.34$ & 28.08 & L. racemosa & 99 & 0 \\
\hline & & & & & A. schaueriana & 1 & 0 \\
\hline
\end{tabular}

racemosa, and A. germinans occur, and by SCHAEFFERNOVELLI et al. (1990), and SANTOS et al. (1997) for regions where mangrove forests are associated with salt flats. According to JIMENEZ; SAUTER (1991), the high salinity levels found in the most inner sites of the mangrove forests they have studied constrain the development of Rhizophora racemosa, in contrast to Avicennia bicolor which tolerates higher salinities. A similar relationship has been described by LARA; COHEN (2006) and PIOU et al. (2006) for Rhizophora mangle and Avicennia germinans.

The interstitial salinity increases with increasing distance from the river, contradicting the pattern reported previously by JOSHI; GHOSE (2003). The initial low salinities can be explained by the higher frequency and duration of tidal flooding after point one. Low frequency and duration of tidal flooding, in a seasonally dry climate such as in the Guaratiba region, are probably the driving factors for the observed high salinity in the landward areas of the intertidal zone. This pattern is responsible for the formation and maintenance of salt flats associated with mangrove forests, as previously described by HUTCHINGS; SAENGER (1987). Results of the directgradient analysis show that different mangrove species have different distributions along the salinity gradient. A.schaueriana and L. racemosa are found in wide ranges of soil salinity, whereas $R$. mangle is restricted to lower salinity levels.

The distribution of mangrove species associated with a gradient of frequency of tidal flooding has been reported by many authors, and may be a response to a salinity gradient (CINTRON et al., 1978; TOMLINSON, 1986; JOSHI; GHOSE, 2003). Despite the importance of salinity control of the mangrove species distribution, we must consider the importance of many other physico-chemical factors (NICKERSON; THIBODEAU, 1985; EWEL et 
Table 3. Structural parameters of transect C.

\begin{tabular}{|c|c|c|c|c|c|c|c|}
\hline \multirow{2}{*}{ Plot } & \multirow{2}{*}{$\begin{array}{l}\text { Density (live } \\
\text { trunks.ha-1) }\end{array}$} & \multirow{2}{*}{$\begin{array}{l}\text { Mean } D_{130} \\
(\mathrm{~cm})\end{array}$} & \multirow{2}{*}{$\begin{array}{c}\text { Mean } \\
\text { Height (m) }\end{array}$} & \multirow{2}{*}{$\begin{array}{c}\text { Basal Area } \\
\left(\mathrm{m}^{2} \cdot \mathrm{h}^{-1}\right)\end{array}$} & \multicolumn{3}{|c|}{ Basal Area Contribution (\%) } \\
\hline & & & & & Species & Live & Dead \\
\hline \multirow{3}{*}{1} & \multirow{3}{*}{6,900} & \multirow{3}{*}{5.66} & \multirow{3}{*}{$4.50 \pm 3.07$} & \multirow{3}{*}{20.83} & R. mangle & 60 & 16 \\
\hline & & & & & L. racemosa & 0 & 0 \\
\hline & & & & & A. schaueriana & 24 & 0 \\
\hline \multirow{3}{*}{2} & \multirow{3}{*}{3,800} & \multirow{3}{*}{8.87} & \multirow{3}{*}{$7.96 \pm 1.73$} & \multirow{3}{*}{33.99} & R. mangle & 47 & 5 \\
\hline & & & & & L. racemosa & 2 & 0 \\
\hline & & & & & A. schaueriana & 20 & 26 \\
\hline \multirow{3}{*}{3} & \multirow{3}{*}{16,286} & \multirow{3}{*}{5.43} & \multirow{3}{*}{$2.90 \pm 1.23$} & \multirow{3}{*}{37.9} & R. mangle & 22 & 0 \\
\hline & & & & & L. racemosa & 2 & 0 \\
\hline & & & & & A. schaueriana & 76 & 0 \\
\hline \multirow{3}{*}{4} & \multirow{3}{*}{47,143} & & & & R. mangle & 5 & 0 \\
\hline & & 1.69 & $1.87 \pm 0.78$ & 11.96 & L. racemosa & 24 & 7 \\
\hline & & & & & A. schaueriana & 59 & 4 \\
\hline & & & & & R. mangle & 2 & 0 \\
\hline 5 & 19,429 & 3.06 & $2.07 \pm 1.07$ & 15.36 & L. racemosa & 28 & 6 \\
\hline & & & & & A. schaueriana & 64 & 1 \\
\hline & & & & & R. mangle & 44 & 0 \\
\hline 6 & 31,143 & 2.25 & $2.34 \pm 1.01$ & 14.0 & L. racemosa & 39 & 11 \\
\hline & & & & & A. schaueriana & 6 & 1 \\
\hline & & & & & R. mangle & 13 & 0 \\
\hline 7 & 14,400 & 3.48 & $3.35 \pm 1.40$ & 23.95 & L. racemosa & 8 & 8 \\
\hline & & & & & A. schaueriana & 36 & 35 \\
\hline & & & & & R. mangle & 0 & 0 \\
\hline 8 & 55,600 & 2.35 & $2.77 \pm 0.85$ & 44.18 & L. racemosa & 22 & 10 \\
\hline & & & & & A. schaueriana & 32 & 36 \\
\hline & & & & & R. mangle & 3 & 0 \\
\hline 9 & 27,600 & 3.97 & $2.75 \pm 1.73$ & 35.35 & L. racemosa & 6 & 1 \\
\hline & & & & & A. schaueriana & 88 & 3 \\
\hline & & & & & R. mangle & 0 & 0 \\
\hline 10 & 31,200 & 2.76 & $3.64 \pm 1.76$ & 21.8 & L. racemosa & 29 & 3 \\
\hline & & & & & A. schaueriana & 56 & 11 \\
\hline & & & & & R. mangle & 0 & 0 \\
\hline 11 & 106,667 & 1.58 & $1.74 \pm 0.66$ & 26.32 & L. racemosa & 38 & 10 \\
\hline & & & & & A. schaueriana & 42 & 10 \\
\hline & & & & & R. mangle & 0 & 0 \\
\hline 12 & 28,000 & 1.95 & $1.58 \pm 0.98$ & 8.52 & L. racemosa & 59 & 2 \\
\hline & & & & & A. schaueriana & 39 & 0 \\
\hline & & & & & R. mangle & 0 & 0 \\
\hline 13 & 21,600 & 2.86 & $1.06 \pm 0.56$ & 14.27 & L. racemosa & 71 & 3 \\
\hline & & & & & A. schaueriana & 26 & 0 \\
\hline & & & & & R. mangle & 0 & 0 \\
\hline 14 & 22,400 & 1.67 & $0.54 \pm 0.46$ & 5.04 & L. racemosa & 70 & 1 \\
\hline & & & & & A. schaueriana & 28 & 1 \\
\hline
\end{tabular}

al., 1998; FELLER et al., 2003; LOVELOCK et al., 2007), which and are also regulated by tidal flooding.

The progressive decrease of structural development towards the transition zone between the forest and the salt flat observed in Guaratiba has also been reported previously for other dry or seasonally dry regions (BALL, 1980; SCHAEFFER-NOVELLI et al., 1990;
CINTRON-MOLERO, 1993; SANTOS et al., 1997). However, such a structural decrease may also occur where the mangrove forest is associated with a terrestrial ecosystem (DAHDOUGH-GUEBAS, 2004; LARADOMÍNGUEZ et al., 2005; KRAUSS et al., 2006).

Such a pattern reflects the environmental severity in the transition zones, which derives from a gradient of tidal 
Table 4. Basal area, live and dead, by $\mathrm{D}_{130}$ class $(\mathrm{cm})$ on transect $\mathrm{A}$.

\begin{tabular}{|c|c|c|c|c|c|c|}
\hline \multirow{2}{*}{ Plot } & \multicolumn{3}{|c|}{ Live basal area $\left(\mathrm{m}^{2} \cdot \mathrm{ha}^{-1}\right)$} & \multicolumn{3}{|c|}{ Dead basal area $\left(\mathrm{m}^{2} \cdot \mathrm{ha}^{-1}\right)$} \\
\hline & $\mathrm{D}_{130}<2.5$ & $2.5 \leq \mathrm{D}_{130}<10.0$ & $\mathrm{D}_{130} \geq 10.0$ & $\mathrm{D}_{130}<2.5$ & $2.5 \leq \mathrm{D}_{130}<10.0$ & $\mathrm{D}_{130} \geq 10.0$ \\
\hline 1 & 0 & 9.86 & 14.88 & 0 & 1.37 & 0 \\
\hline 2 & 0.05 & 6.46 & 12.72 & 0.04 & 0.88 & 0 \\
\hline 3 & 0.75 & 9.77 & 9.98 & 0.39 & 1.58 & 2.65 \\
\hline 4 & 1.57 & 8.23 & 3.65 & 0.72 & 0.98 & 0 \\
\hline 5 & 4.76 & 8.58 & 0.95 & 0.48 & 0.26 & 0 \\
\hline 6 & 4.23 & 57.5 & 0 & 0.17 & 0.23 & 0 \\
\hline 7 & 0 & 51.96 & 0 & 0 & 0 & 0 \\
\hline 8 & 3.6 & 26.27 & 7.13 & 0 & 0.24 & 0 \\
\hline
\end{tabular}

Table 5. Basal area. live and dead. by $\mathrm{D}_{130}$ classes $(\mathrm{cm})$ at transect $\mathrm{B}$.

\begin{tabular}{|c|c|c|c|c|c|c|}
\hline \multirow{2}{*}{ Plot } & \multicolumn{3}{|c|}{ Live basal area $\left(\mathrm{m}^{2} \cdot \mathrm{ha}^{-1}\right)$} & \multicolumn{3}{|c|}{ Dead basal area $\left(\mathrm{m}^{2} \cdot \mathrm{ha}^{-1}\right)$} \\
\hline & $\mathrm{D}_{130}<2.5$ & $2.5 \leq \mathrm{D}_{130}<10.0$ & $\mathrm{D}_{130} \geq 10.0$ & $\mathrm{D}_{130}<2.5$ & $2.5 \leq \mathrm{D}_{130}<10.0$ & $\mathrm{D}_{130} \geq 10.0$ \\
\hline 1 & 0 & 13.76 & 7.98 & 0 & 3.04 & 1.84 \\
\hline 2 & 0.32 & 8.86 & 8.61 & 0.12 & 3.19 & 0 \\
\hline 3 & 0.12 & 10.17 & 6.97 & 0.15 & 1.16 & 7.26 \\
\hline 4 & 2.02 & 10.37 & 12.37 & 0.75 & 1.84 & 0 \\
\hline 5 & 2.8 & 8.78 & 0 & 1.64 & 1.16 & 0 \\
\hline 6 & 3.49 & 10.18 & 10.28 & 1.5 & 1.62 & 0 \\
\hline 7 & 6.17 & 11.44 & 2.64 & 2.03 & 0.83 & 0 \\
\hline 8 & 9.98 & 17.79 & 0 & 1.52 & 0.15 & 0 \\
\hline 9 & 14.09 & 3.32 & 0 & 3.37 & 0.38 & 0 \\
\hline 10 & 1.58 & 26.51 & 0 & 0 & 0 & 0 \\
\hline
\end{tabular}

Table 6. Basal area. live and dead. by $\mathrm{D}_{130}$ class $(\mathrm{cm})$ on transect $\mathrm{C}$.

\begin{tabular}{|c|c|c|c|c|c|c|}
\hline \multirow{2}{*}{ Plot } & \multicolumn{3}{|c|}{ Live basal area $\left(\mathrm{m}^{2} \cdot \mathrm{ha}^{-1}\right)$} & \multicolumn{3}{|c|}{ Dead basal area $\left(\mathrm{m}^{2} \cdot \mathrm{ha}^{-1}\right)$} \\
\hline & $\mathrm{D}_{130}<2.5$ & $2.5 \leq \mathrm{D}_{130}<10.0$ & $\mathrm{D}_{130} \geq 10.0$ & $\mathrm{D}_{130}<2.5$ & $2.5 \leq \mathrm{D}_{130}<10.0$ & $\mathrm{D}_{130} \geq 10.0$ \\
\hline 1 & 0.71 & 6.78 & 9.84 & 0.15 & 0.39 & 2.96 \\
\hline 2 & 0 & 12.39 & 11.09 & 0 & 0.86 & 9.65 \\
\hline 3 & 2.0 & 10.93 & 0 & 0.16 & 0 & 0 \\
\hline 4 & 7.79 & 2.81 & 0 & 1.36 & 0 & 0 \\
\hline 5 & 2.99 & 4.34 & 0 & 0.52 & 0.55 & 0 \\
\hline 6 & 5.16 & 7.26 & 0 & 1.17 & 0.4 & 0 \\
\hline 7 & 1.46 & 12.2 & 0 & 1.09 & 3.22 & 5.99 \\
\hline 8 & 9.62 & 14.42 & 0 & 4.25 & 8.91 & 6.97 \\
\hline 9 & 3.32 & 11.98 & 0 & 0.77 & 0 & 0 \\
\hline 10 & 4.12 & 14.52 & 0 & 2.92 & 0 & 0 \\
\hline 11 & 14.35 & 6.65 & 0 & 4.99 & 0 & 0 \\
\hline 12 & 5.09 & 3.26 & 0 & 0.09 & 0 & 0 \\
\hline 13 & 2.24 & 11.63 & 0 & 0.04 & 0 & 0 \\
\hline 14 & 4.04 & 0.88 & 0 & 0.12 & 0 & 0 \\
\hline
\end{tabular}

frequency (KRAUSS et al., 2008), leading to gradients of salinity (SAM; RIDD, 1998; ELLISON et al., 2000), nutrients concentration and availability (NICKERSON; THIBODEAU, 1985; EWEL et al., 1998) and concentration of $\mathrm{H}_{2} \mathrm{~S}$ (FELLER et al., 2003; LOVELOCK et al., 2007). As a result, the space tends to be sparsely occupied by individuals of low structural development in the transition zones. In other words, under adverse conditions, the available space is not fully occupied, contrary to what occurs in forests under better environmental conditions. This confirms the third hypothesis of this study. This hypothesis is in accordance with ODUM (1985), who stated 


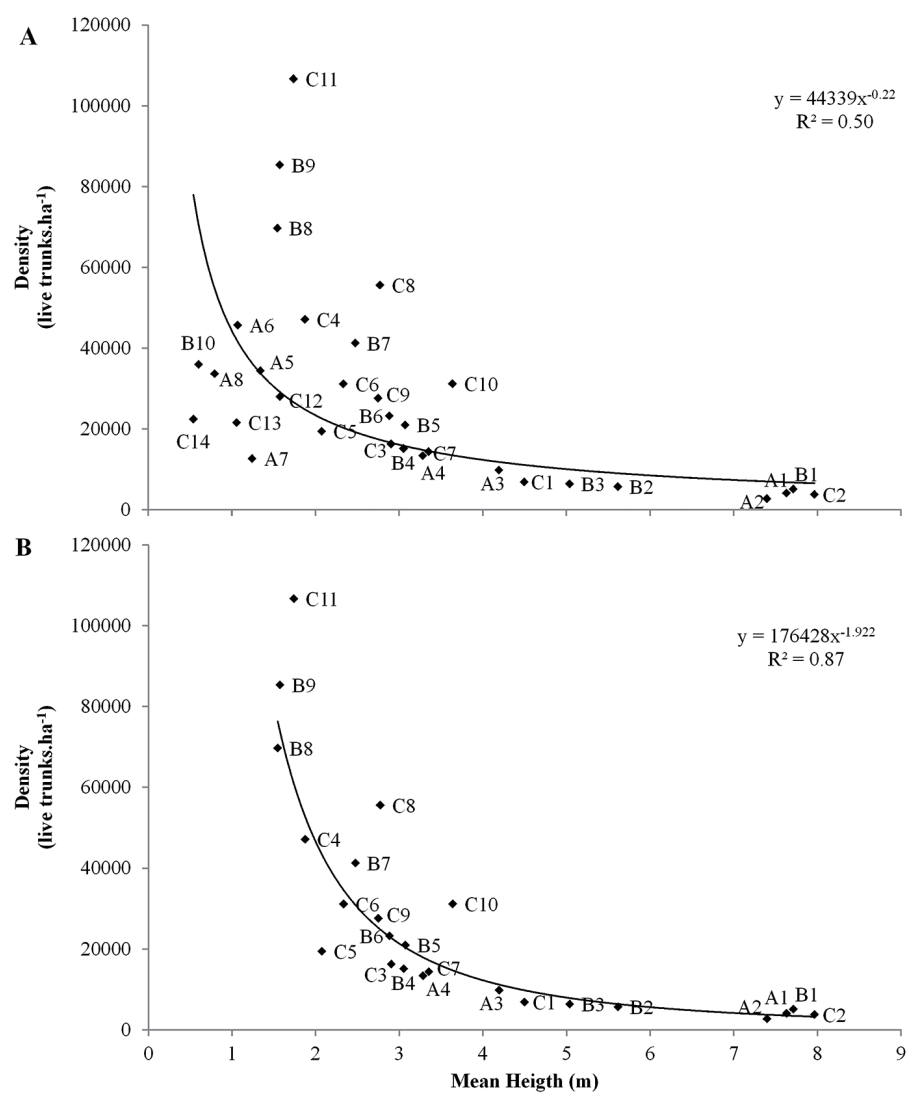

Figure 3. Regression analysis relating density and mean height (A) including all plots studied and (B) excluding plots located at the transition between mangrove forests and the salt flat (A5, A6, A7, A8, B10, C12, C13 and C14).

that in ecosystems under stress, organisms become smaller in size and resource utilization becomes less efficient, such as the case of space in the present study.

The occurrence of a zone with reduced mean height and trunk density at the transition between mangroves and salt flats has been reported by SOARES et al. (2008) in NE-Brazil, where only individuals of A. schaueriana were found and had a dead basal area of $45 \%$. Landward from this zone, $99 \%$ of the individuals were dead. GORDON (1993) has previously shown that shrub-like forests, characterized by low structural development and density, occur at transition zones between mangroves and salt flats. These findings have been reinforced by MEDINA et al. (2001) as well, who have described the occurrence of shrub-like, sparse forests of A. germinansin sites where salinity levels were higher than 60 .

BALL (1980) observed that zones with low tidal flooding frequency are subjected to extreme conditions, such as substrate dehydration and wide variability in salinity levels, as opposed to areas with high tidal frequency, and more stable environmental conditions. Discussing the same topic, JIMENEZ (1990) showed that high rates of mortality of low-size classes associated with environmental severity (water stress) leads to low density of trees.

In the light of these facts, the relationship between density and mean height (Figure 3A) does not clearly describe the complex relationship between density and structural development (represented by mean height), since it includes sampling sites subjected to different regimes of tidal flooding and levels of stress. As shown in the results section, Figure $3 \mathrm{~A}$ includes zones where the relationship between density and height is inverse (different maturation phases) and zones where this relationship does not occur (sites under high environmental severity). ARREOLALIZÁRRAGA et al. (2004) described a similar pattern for mangroves in the Gulf of California, where hypersalinity limits forest development. These forests have low density, 

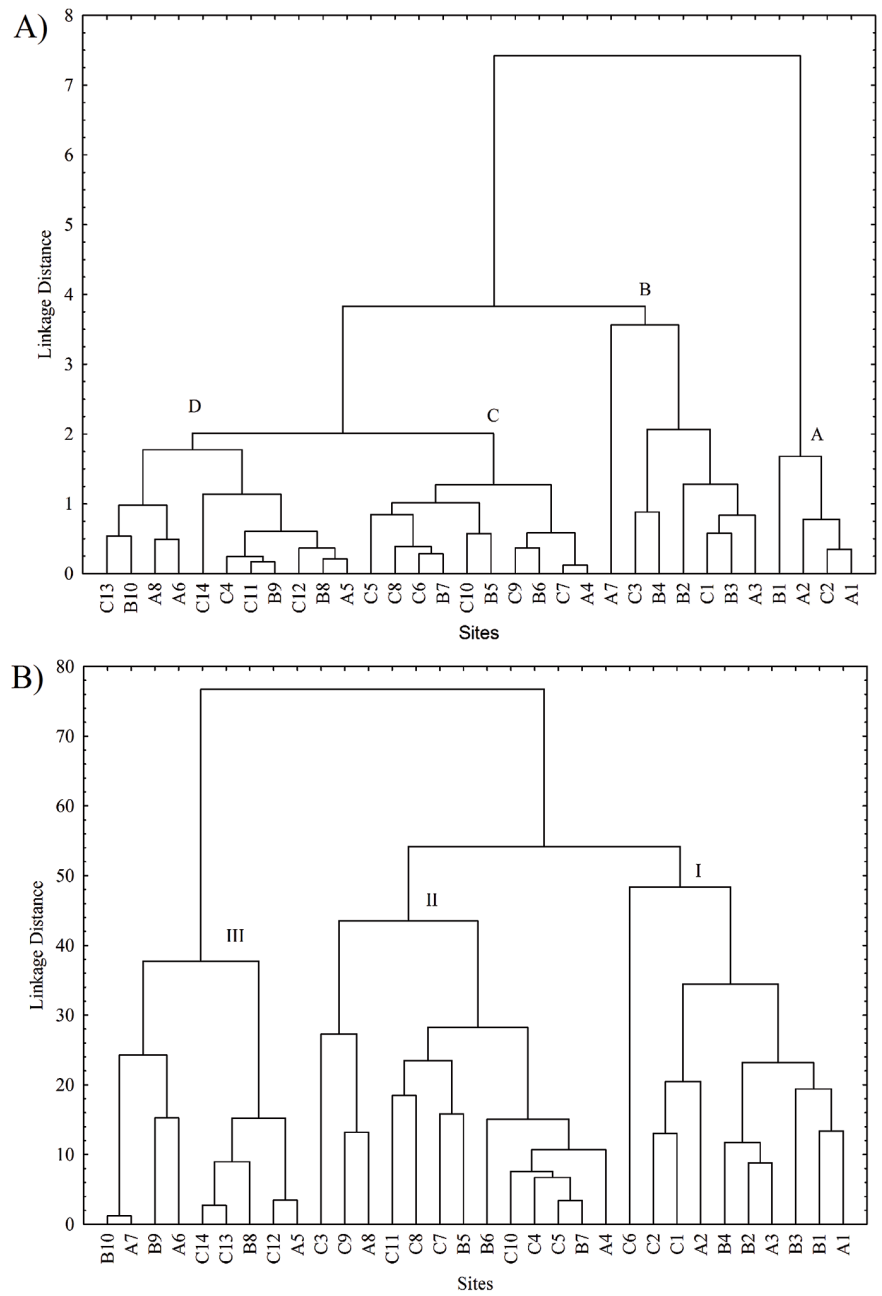

Figure 4. Cluster analysis (UPGMA) of sites studied (A) considering mean $\mathrm{D}_{130}$ and mean height and (B) considering live basal area contribution (\%) of each species.

but also low height and basal area, exactly as plots A5, $\mathrm{A} 6, \mathrm{~A} 7, \mathrm{~A} 8, \mathrm{~B} 10, \mathrm{C} 12, \mathrm{C} 13$ and $\mathrm{C} 14$, at the transition zone, do. As described earlier, by excluding these plots from the analysis, the effects of maturation of the selected forests could be demonstrated without the "noise" from the variability inserted by stress (Figure $3 \mathrm{~B} ; \mathrm{R}^{2}=0.87$; $<0.05)$.

With some few exceptions, plots classified as fringe forests were defined as Groups A and B in the cluster analysis, while plots classified as basin and transition forests were defined as Groups C and D, respectively. This pattern highlights the relationship between structural development and tidal flooding frequency, which is in agreement with the findings of previous studies, such as CINTRON et al. (1978); SCHAEFFER-NOVELLI et al. (1990); JIMENEZ; SAUTER (1991); EWEL et al. (1998);
FELLER et al. (2003); DAHDOUH-GUEBAS et al. (2004); LARA-DOMÍNGUEZ et al. (2005); KRAUSS et al. (2006); LARA; COHEN (2006) and ESTRADA et al. (2013). The mangrove forests of Guaratiba, located in a protected area (Biological Reserve of Guaratiba), undergo little human interference. Consequently, the low structural development found at some sites reflects the influence of natural factors associated with environmental severity caused by low frequency of tidal flooding at the interface between mangrove forests and the salt flat. In contrast, mangrove forests with low structural development in the Guanabara Bay (Table 7), for example, are under strong human pressure (SOARES et al., 2003; CAVALCANTI et al., 2009).

Although some plots in Guaratiba showed low structural development as demonstrated by mean height parameters, 
Table 7. Structural parameters for other mangrove forests in Rio de Janeiro state, between $21^{\circ} 18^{\prime}$ and $23^{\circ} 23^{\prime} \mathrm{S}$.

\begin{tabular}{lcccc}
\hline Study Area & Mean Diameter $(\mathrm{cm})$ & Mean Height $(\mathrm{m})$ & Basal Area $\left(\mathrm{m}^{2} . \mathrm{ha}^{-1}\right)$ & Reference \\
\hline Itacuruçá & 7.80 & $6.10 \pm 1.20$ & 21.6 & SILVA et al. (1991) \\
Tijuca Lagoon & $4.80-16.67$ & $3.37-11.58$ & $14.25-41.37$ & SOARES (1999) \\
Itabapoana River & $3.70-13.50$ & $4.00-10.10$ & $13.50-48.30$ & BERNINI; REZENDE (2010) \\
Paraíba do Sul River & $7.44-13.40$ & $6.30-9.90$ & $14.50-35.30$ & BERNINI; REZENDE (2004) \\
Suruí River & $5.16-7.11$ & $4.90-6.58$ & $0.61-17.17$ & SOARES et al. (2003) \\
Nova Orleans & $4.31-6.49$ & $4.31-6.49$ & $12.91-20.00$ & SOARES et al. (2003) \\
Piedade & $1.73-7.83$ & $2.40-6.72$ & $9.84-18.16$ & SOARES et al. (2003) \\
Duque de Caxias & $1.33-7.42$ & $1.80-6.20$ & $1.10-24.02$ & SOARES et al. (2003) \\
São Gonçalo I & $3.65-5.56$ & $3.33-6.37$ & $11.72-17.78$ & SOARES et al. (2003) \\
São Gonçalo II & $4.22-6.56$ & $3.86-7.27$ & $9.45-15.74$ & SOARES et al. (2003) \\
Guanabara Bay PA & $8.38 \pm 1.96$ & $7.46 \pm 1.96$ & $16.04 \pm 3.92$ & CAVALCANTI et al. (2009) \\
Guanabara Bay & $5.07 \pm 1.53$ & $4.86 \pm 1.38$ & $13.20 \pm 4.87$ & CAVALCANTI et al. (2009) \\
Piracão River & $1.61-9.46$ & $0.54-7.96$ & $4.92-62.74$ & Present study \\
\hline
\end{tabular}

Footnotes: 1. Parameters calculated from 43 plots located in two Protected Areas; 2. Parameters calculated from 30 plots.

their live basal areas reflect the degree of conservation. Forests in degraded areas, such as those described by SOARES et al. (2003) for Guanabara Bay, contain less than $20.0 \mathrm{~m}^{2} \cdot \mathrm{ha}^{-1}$ of basal area. On the other hand, $72 \%$ of the forests studied in Guaratiba have more than $20.0 \mathrm{~m}^{2} \cdot \mathrm{ha}^{-1}$ of basal area, and about $22 \%$ of them have more than $30.0 \mathrm{~m}^{2}$.ha-1.

In summary, the analysis of the forest structure in the selected region allowed us to describe the structural variability of a mangrove forest associated to a gradient of tidal flooding frequency. Along this gradient, soil environmental severity increases and reaches maximum levels in the salt flat, where no mangrove plant occur. On one end of this gradient, the forest is well developed and dominated by $R$. mangle; whereas on the other end the forest is characterized by low structural development and dominated by $A$. schaueriana and $L$. racemosa. This pattern is similar to other mangroves from dry or seasonally dry regions where a gradient of tidal frequency toward the transition zone is observed. Low structure development found at the transition between the forest and the salt flat is probably determined by natural stressors, such as hypersalinity, nutrient depletion, and high $\mathrm{H}_{2} \mathrm{~S}$ concentration. These stressors are associated with low tidal frequency, and must not be confused with anthropogenic disturbances that lead to similar structural characteristics.

\section{ACKNOWLEDGEMENTS}

The authors thank Fundação Carlos Chagas Filho de Amparo à Pesquisa do Estado do Rio de Janeiro (FAPERJ), for the financial support, Empresa Brasileira de Pesquisa Agropecuária (Embrapa), for the logistical support, and Instituto Estadual do Ambiente (INEA-RJ) for granting the authorization to conduct the field sampling.

\section{REFERENCES}

ARREOLA-LIZÁRRAGA, J. A.; FLORES-VERDUGO, F. J.; ORTEGA-RUBIO, A. Structure and litterfall of an arid mangrove stand on the Gulf of California, Mexico. Aquat. Bot., v. 79, n. 2, p. 137-143, 2004.

BALL, M. C. Patterns of secondary succession in a mangrove forest of southern Florida. Oecologia, v. 44, n. 2, p. 226-235, 1980.

BERGER, U.; RIVERA-MONROY, V. H.; DOYLE, T. W.; DAHDOUH-GUEBAS, F.; DUKE, N. C.; FONTALVO-HERAZO, M. L.; HILDENBRANDT, H.; KOEDAM, N.; MEHLIG, U.; PIOU, C.; TWILLEY, R. R. Advances and limitations of individual-based models to analyze and predict dynamics of mangrove forests: A review. Aquat. Bot., v. 89, n. 2, p. 260-274, 2008.

BERNINI, E.; REZENDE, C. E. Vegetation structure of the mangrove forest at the estuary Paraíba do Sul river, Rio de Janeiro, Brazil. Acta Bot. Bras., v. 18, n. 3, p. 491-502, 2004.

BERNINI, E.; REZENDE, C. E. Structural variation in mangrove forests of the estuary of the River Itabapoana, ES-RJ. Biotemas, v. 23, n. 1, p. 49-60, 2010.

BROKAW, N.; THOMPSON, J. The H for DBH. For. Ecol. Manage., v. 129, n. 1/3, p. 89-91, 2000.

CAVALCANTI, V. F.; SOARES, M. L. G.; ESTRADA, G. C. D.; CHAVES, F. O. Evaluating mangrove conservation through the analysis of Forest structure data. J. Coast. Res., v. 56, p. 390-394, 2009.

CHAPMAN, V.J. Mangrove biogeography. In: WALSH, G.E; SNEDAKER, S. C.; TEAS, H.J. (Eds.). International symposium on biology and management of mangroves. Honolulu, Hawaii. p. 3-22, 1976.

CINTRON, G.; LUGO, A. E.; POOL, D. J.; MORRIS, G. Mangroves of arid environments in Puerto Rico and adjacent islands. Biotropica, v. 10, n. 2, p. 110-121, 1978.

CINTRON, G.; SCHAEFFER-NOVELLI, Y. Methods for studying mangrove structure. In: SNEDAKER, S. C.; SNEDAKER, J. G. (Eds.). The mangrove ecosystem: Research Methods. Bungay: UNESCO, 1984. 251 p.

CINTRON-MOLERO, G. Mangroves of arid regions of Puerto Rico and the Caribbean. In: LIETH, H.; AL MASOOM, A. (Eds.). Towards the rational use of high salinity tolerant plants. Zurich: Kluwer Academic Publishers, 1993. 521 p. 
DAHDOUGH-GUEBAS, F.; DE BONDT, R.; ABEYSINGHE, P. D. Comparative study of the disjunct zonation pattern of the grey mangrove Avicennia marina (forsk.) vierh. in Gazi Bay (Kenya). Bull. Mar. Sci., v. 74, n. 2, p. 237-252, 2004.

DANSEREAU, P. Zonation et succession sur la restinga de Rio de Janeiro. - I. Halosère. Rev. Can. Montr., v. 6, n. 3, p. 448477, 1947.

ELLISON, A. M.; MUKHERJEE, B. B.; KARIM, A. Testing patterns of zonation in mangroves: scale dependence and environmental correlates in the Sundarbans of Bangladesh. $J$. Ecol., v. 88, n. 5, p. 813-824, 2000.

ESTRADA, G. C. D.; CALlADO, C. H.; SOARES, M. L. G.; LISI, C. S. Annual growth rings in the mangrove Laguncularia racemosa (Combretaceae). Trees, v. 22, n. 5, p. 663-670, 2008;

ESTRADA, G. C. D.; SOARES, M. L. G.; CHAVES, F. O.; CAVALCANTI, V. F. Analysis of the structural variability of mangrove forests through the physiographic types approach. Aquat. Bot., v. 111, p. 135-143, 2013.

EWEL, K. C.; BOURGEOIS, J. A.; COLE, T. G. Variation in environmental characteristics and vegetation in high-rainfall mangrove forests, Kosrae, Micronesia. Glob. Ecol. Biogeogr. Lett., v. 7, n. 1, p. 49-56, 1998.

FELLER, I. C.; MCKEE, K. L.; WHIGHAM, D. F.; O’NEILL, J. P. Nitrogen vs. phosphorus limitation across an ecotonal gradient in a mangrove forest. Biogeochemistry, v. 62, n. 2, p. 145-175, 2003.

FRELICH, L. E. Forest Dynamics and Disturbances Regimes: Studies from Temperate Evergreen-Deciduous Forests. Cambridge: Cambridge University Press, 2002. 266 p.

GORDON, D. M. Diurnal water relations and the salt content of two contrasting mangroves growing in hypersaline soils in tropical-arid Australia. In: LIETH, H.; AL MASOOM, A. (Eds.). Towards the rational use of high salinity tolerant plants. Zurich: Kluwer Academic Publishers, 1993. p. 193216.

HUSTON, M. A. Biological Diversity - The Coexistence of Species on Changing Landscapes. Cambridge: Cambridge University Press, 1996. 704 p.

HUTCHINGS, P. A.; SAENGER, P. Ecology of Mangroves. Brisbane: University of Queensland Press, 1987. 388 p.

JIMÉNEZ, J. A. The structure and function of dry weather mangroves on the Pacific coast of Central America, with emphasis on Avicennia bicolor forests. Estuaries, v. 13, n. 2, p. 182192, 1990.

JIMÉNEZ, J. A; SAUTER, K. Structure and dynamics of mangrove forests along a flooding gradient. Estuaries, v. 14, n. 1, p. 49-56, 1991.

JOSHI, H.; GHOSE, M. Forest structure and species distribution along soil salinity and $\mathrm{pH}$ gradient in mangrove swamps of the Sundarbans. Trop. Ecol., v. 44, n. 2, p. 197-206, 2003.

KRAUSS, K. W.; KEELAND, B. D.; ALLEN, J. A.; EWEL, K. C.; JOHNSON, D. J. Effects of season, rainfall, and hydrogeomorphic setting on mangrove tree growth in Micronesia. Biotropica, v. 39, n. 2, p. 161-170, 2007.

KRAUSS, K. W.; LOVELOCK, C. E.; MCKEE, K. L.; LÓPEZ-HOFFMAN, L.; EWE, S. M. L.; SOUSA, W. P. Environmental drivers in mangrove establishment and early development: a review. Aquat. Bot., v. 89, n. 2, p. 105-127, 2008.
LARA, R. J.; COHEN, M. C. L. Sediment porewater salinity, flooding frequency and mangrove vegetation height in Bragança, North Brazil: an ecohydrology-based empirical model. Wetl. Ecol. Manag., v. 14, n. 4, p. 349-358, 2006.

LARA-DOMÍNGUEZ, A. L.; DAY JR, J. W.; ZAPATA, G. V. Structure of a unique inland mangrove forest assemblage in fossil lagoons on the Caribbean Coast of Mexico. Wetl. Ecol. Manag., v. 13, p. 111-122, 2005.

LOVELOCK, C. E.; FELLER, I. C.; ELLIS, J.; SCHWARZ, A. M.; HANCOCK, N.; NICHOLS, P.; SORRELL, B. Mangrove growth in New Zealand estuaries: the role of nutrient enrichment at sites with contrasting rates of sedimentation. Oecologia, v. 153, n. 3, p. 633-641, 2007.

LUGO, A.E.; SNEDAKER, S.C. The ecology of mangroves. Ann. Rev. Ecol. Syst., v. 5, p. 39-64, 1974.

MEDINA, E.; GIARRIZZO, T.; MENEZES, M. P.; CARVALHO, M. L.; CARVALHO, E. A.; PERES, A.; SILVA, A. B.; VIILHENA, R.; REISE, A.; BRAGA, C. Mangal communities of the Salgado Paraense: ecological heterogeneity along the Bragança peninsula assessed through soil and leaf analyses. Amazoniana, v. 16, n. 3/4, p. 397-416, 2001.

NICKERSON, N. H.; THIBODEAU, F. R. Association between pore water sulfide concentrations and the distribution of mangroves. Biogeochemistry, v. 1, n. 2, p. 183-192, 1985.

ODUM, E. P. Trends expected in stressed ecosystems. BioScience, v. 35, n. 7, p. 419-422, 1985.

OLIVER, C. D.; LARSON, B. C. Forest Stand Dynamics. New York: McGraw-Hill, 1990. 544 p.

PIOU, C.; FELLER, I. C.; BERGER, U.; CHI F. Zonation patterns of Belizean offshore mangrove forests 41 years after a catastrophic hurricane. Biotropica, v. 38, n. 3, p. 365-374, 2006.

RIDD, P. V.; SAM, R. Profiling Groundwater Salt Concentrations in Mangrove Swamps and Tropical Salt Flats. Estuar. Coast. Shelf Sci., v. 43, n. 5, p. 627-635, 1996.

SAM, R.; RIDD, P. Spatial variations of groundwater salinity in a mangrove-salt flat system, Cocoa Creek, Australia. Mangr. Salt Mar., v. 2, n. 3, p. 121-132, 1998.

SANTOS, M. C. F. V.; ZIEMAN, J. C.; COHEN, R. R. H. Interpreting the upper mid-littoral zonation patterns of mangroves in Maranhão (Brazil) in response to microtopography and hydrology. In: KJERFVE, B.; LACERDA, L. D.; DIOP, E. H. S. (Eds.). Mangrove Ecosystems Studies in Latin America and Africa. Paris: UNESCO, 1997. p. 127-144.

SCHAEFFER-NOVELLI, Y.; CINTRÓN-MOLERO, G.; ADAIME, R. R.; CAMARGO, T. M. Variability of mangrove ecosystems along the Brazilian coast. Estuaries, v. 13, n. 2, p. 204-218, 1990.

SCHAEFFER-NOVELLI, Y.; CINTRÓN-MOLERO, G.; SOARES, M. L. G.; DE-ROSA, T. Brazilian mangroves. Aquat. Ecosyst. Health Manag., v. 3, n. 4, p. 561-570, 2000.

SHERMAN, R. E.; FAHEY, T. J.; BATTLES, J. J. Small-scale disturbance and regeneration dynamics in a neotropical mangrove forest. J. Ecol., v. 88, n. 1, p. 165-178, 2000.

SILVA, C. A. R.; LACERDA, L. D.; SILVA, L. F. F.; REZENDE, C. E. Forest structure and biomass distribution in a red mangrove stand in Sepetiba Bay, Rio de Janeiro. Rev. Bras. Bot., v. 14, p. 21-25, 1991. 
SMITH, T. J. Forest structure. In: ROBERTSON, A. I.; ALONGI, D. M. (Eds.). Tropical mangrove ecosystems. Washington: American Geophysical Union, 1992. p. 101-136.

SOARES, M. L. G. Structure and degree of perturbation of mangroves at Tijuca Lagoon, Rio de Janeiro, RJ, Brazil. Rev. Bras. Biol., v. 59, p. 503-51, 1999.

SOARES, M. L. G.; CHAVES, F. O.; CORRÊA, F. M.; SILVA JÚNIOR, C. M. G. Diversidade Estrutural de Bosques de Mangue e sua Relação com Distúrbios de Origem Antrópica: o caso da Baía de Guanabara (Rio de Janeiro). Anu. Inst. Geocienc. UFRJ, v. 26, p. 101-116, 2003.

SOARES, M. L. G.; CHAVES, F. O.; ESTRADA, G. C. D.; CAVALCANTI, V. F.; PORTUGAL, A. M. M.; BARBOSA, B. Characterization of mangrove forests from the Caravelas Estuarine Complex (Bahia - Brazil). Bol. Tec. Cient. CEPENE Tamandaré, v. 16, n. 5, p. 23-41, 2008.
TOMLINSON, P. B. The Botany of Mangroves. Cambridge: Cambridge University Press, 1986. 419 p.

TWILLEY, R. R. Properties of mangrove ecosystems related to the energy signature of coastal environments. In: HALL, C. (Ed.). Maximum Power. Boulder: University of Colorado Press, 1995. p. 43-61.

VICENTE, J. F.; CARVALHO, M. G.; BARBOSA, G. R. Avaliação Hidrogeológica das Regiões Administrativas de Campo Grande e Guaratiba / RJ. In: Anais do XVI Congresso Brasileiro de Águas Subterrâneas, São Luis - MA, 2010.

WALSH, G. E. Mangroves: a review. In: REIMOLD, R. J; QUEEN, W. H. (Eds.). Ecology of halophytes. New York: Academic Press, 1974. p. 51-174. 